\title{
SUBCUTANEOUS HAEMORRHAGES IN RHEUMATOID PATIENTS TREATED WITH PREDNISONE*
}

\author{
BY \\ GUNTER M. NASHELSKY $\dagger$ AND CHARLEY J. SMYTH \\ From the Department of Medicine, University of Colorado School of Medicine, Denver, Col.
}

Numerous reports have recently appeared calling attention to skin haemorrhages in patients receiving prednisone and prednisolone (Black, Yielding, and Bunim, 1957; Denko and Schroeder, 1957; Boland, 1956, 1957; Solem and Rømcke, 1956; Neustadt, McClendon, Olash, and Best, 1956; Kinsell, Michaels, Coehlo, Foreman, and Friskey, 1955; Brown, 1956).

The occurrence of these ecchymotic lesions has usually been listed among the other side-effects of therapy with these newer steroid substances. Boland (1956) reported that 24 of seventy patients (34 per cent.) receiving prednisone and prednisolone developed subcutaneous haemorrhages, but the report by Denko and Schroeder (1957) is the only detailed study of this toxic manifestation to these steroids. They observed a 20 per cent. incidence of purpuric lesions in a series of 75 patients who received these drugs. Similar lesions were previously observed in patients receiving the original or older steroid preparations (cortisone, hydrocortisone, and corticotropin); however, it has been our experience that this bleeding tendency has appeared with increased frequency since the introduction of the so-called delta- 1 or meta drugs. The purpose of this report is to call attention to these purpuric lesions and to summarize some studies that have been carried out in an effort to explain the mechanism of their production.

\section{Clinical Observations}

In the past 12 months, 44 patients under treatment for rheumatoid arthritis at the Arthritis Clinic of the University of Colorado Medical Centre have been observed who developed superficial haemorrhagic

* This report was presented in part at the Regional Meeting of the American College of Physicians, Colorado Springs, January 19, 1957. $\dagger$ Trainee in Rheumatology of the U.S. Public Health Service (Training Grant 2A-5073). Current address: 2320 Sutter Street, San Francisco 15, California. Supported by grants from the Boettcher Foundation, Denver, Colorado. areas in the skin while receiving long-term corticosteroid therapy. During this period a total of 153 patients with rheumatoid arthritis were under active therapy, of whom 109 received prednisone. Thus, the occurrence of subcutaneous haemorrhages in 44 patients represents an incidence of 40 per cent. of this toxic reaction. In most instances these patients had previously received the older forms of steroids (cortisone and/or hydrocortisone) for periods ranging from months to years. In this group it was not until the introduction of prednisone that the increased incidence of these vascularo lesions became obvious both to the patients and to the physicians responsible for their care. The dailyo amount of prednisone administered in this group of patients varied from 10 to $20 \mathrm{mg}$. per day in three or four equal doses.

Haemorrhagic Lesions.-Most commonly, the patients reported that they "just noticed" the purpuric spots on their skin. Questioning revealed that the haemorrhages frequently came on without apparent cause, but some could recall having received a minor trauma shortly before the onset of the skin changes. A number of patients observed their rapid development and witnessed a gradual spread to their maximum size within 10 to 15 minutes. These lesions were painless and associated with no other complaints. They varied in size from a few millimetres to extensive areas covering as much as half a forearm and appearing as a large ecchymosis. The smaller lesions appeared at times as a telangiectasia. A typical haemorrhagic lesion was round or oval, flat, and about $1 \mathrm{~cm}$. in diameter (Fig. 1, opposite). When they appeared these areas were discrete and of a bright red colour; this deepened on the following day and slowly went through the colour changes of a bruise, finally fading completely in 10 to 15 days; only rarely did the lesions remain longer as pigmented patches of a brownish-tan colour. If the skin overlying a few 


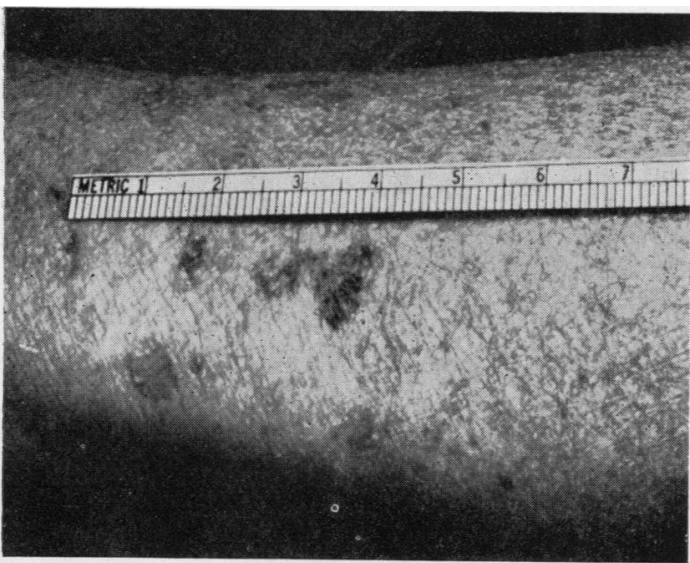

Fig. 1.-Skin of forearm showing several small and one large haemorrhagic area, the largest measuring $1.5 \mathrm{~cm}$.

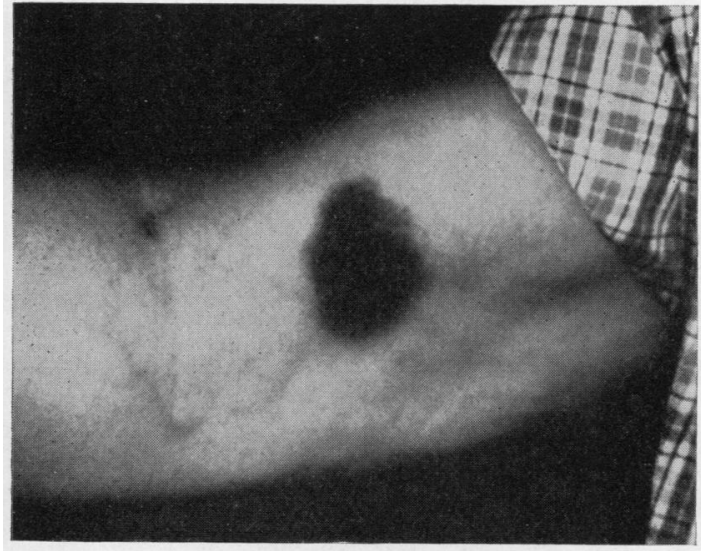

A

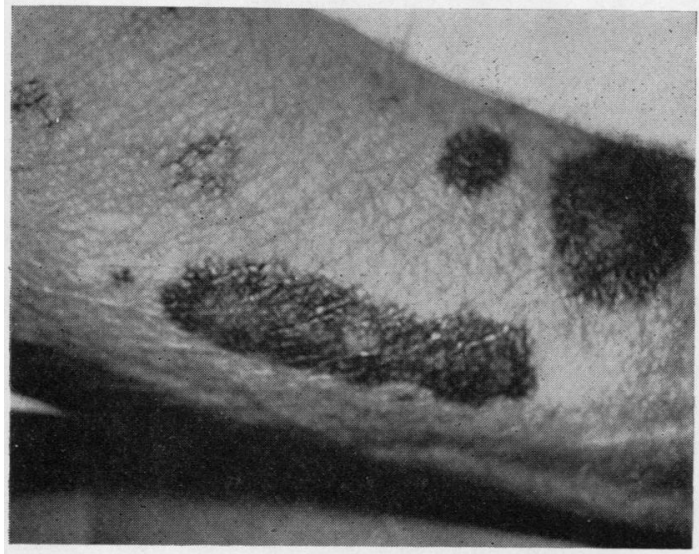

C of the recently developed spots was broken by some minor injury, such as a scratch, it oozed a few drops of blood, but healed normally. In this series of patients the forearms, wrists, and dorsa of the hands and fingers were most common sites, less frequently these purpuric lesions were seen on the neck, shoulders, upper arms, and face, and a few occurred on the lower extremities. Examples of the variety of lesions observed are illustrated in Fig. 2. This distribution to the extremities, face, and neck indicates that the areas of predilection are those constantly subjected to minor trauma. When large ecchymotic areas developed a history of a direct blow or a fall was usually obtained.

These skin manifestations were not seen in patients below the age of 30 years. In no instance was there evidence of internal haemorrhage. In a few patients prednisone was withdrawn, and in these

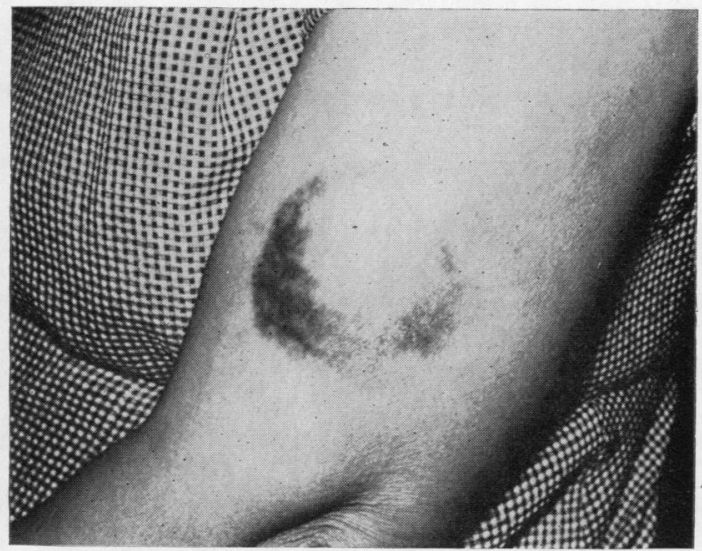

B

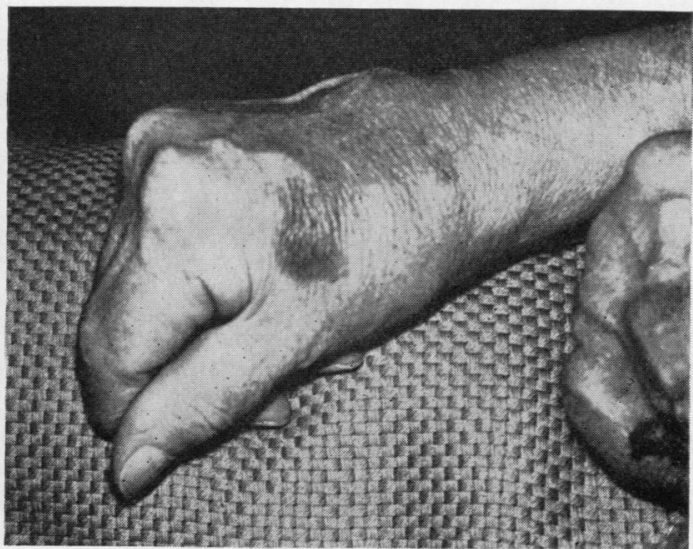

D

Fig. 2.-Four patients, A, B, C, D, showing characteristic haemorrhagic lesions in the skin of the upper extremity. 
the skin lesions disappeared; in several others, the dose was reduced to $5 \mathrm{mg}$. per day, but even with this smaller amount of the hormone this haemorrhagic tendency continued.

Production of Haemorrhagic Lesions.-The influence of minor trauma in the formation of these lesions was easily demonstrated. In several patients with this steroid-induced bleeding tendency, lesions similar to those occurring spontaneously were produced by mechanical trauma. The injury was accomplished with minimal discomfort by the quick snapping action of a wooden spatula held close to the skin of the forearm of the subject. Within a few seconds of this blunt blow petechiae appeared in the areas of skin which had just been struck. The induced haemorrhages could be seen to reach their maximum size in a period of 15 minutes.

\section{Laboratory Observations}

The first eleven of these 44 subjects were selected for extensive laboratory studies, to determine, if possible, the mechanism of production of this observed phenomenon. A summary of the clinical and routine laboratory data concerning the observed haemorrhagic lesions is shown in Table $I$ and in Table II (opposite).

The sensitized sheep erythrocyte agglutination reaction by the modified Ziff technique (Ziff, Brown, and McEwen, 1954) was positive in eight patients; this test was not obtained in the other three patients. A preparation of the peripheral blood for L.E. cells was performed in every case, and only one was positive. The routine serologic test for syphilis (V.D.R.L.) was positive in two patients. The erythrocyte sedimentation rate (Westergren) was raised in each subject. The white blood cell count was slightly raised in each subject, averaging 12,000 cells per c.mm. The haematocrit values were within normal limits. The results of other special blood studies are summarized in Table III (opposite).

In those patients in whom the platelet count, bleeding time, coagulation time, and prothrombin time were determined, the results were within normal limits.

The capillary resistance of the skin at the elbow on the volar surface was measured by the application of a negative pressure suction cup. The instrument* used in this test of capillary fragility permitted the application of a constant negative pressure to a measured area of skin surface. The cup was round with inner diameter $1.7 \mathrm{~cm}$. A negative pressure of $20 \mathrm{~mm}$. $\mathrm{Hg}$ was applied to the skin for exactly one minute. Using this technique, nine of the ten patients studied had no increased capillary fragility.

The capillary fragility was also tested in six of the eleven patients by the Rumpel-Leede test. The sphygmomanometer was applied to the upper arm

* Benoit. E., Paris, France; designed by Lavoluit.

TABLE I

PARTICULARS OF THERAPY IN ELEVEN PATIENTS

\begin{tabular}{|c|c|c|c|c|c|c|c|c|c|}
\hline \multirow{4}{*}{$\begin{array}{l}\text { Patient } \\
\text { No. }\end{array}$} & \multirow{4}{*}{ Sex } & \multirow{4}{*}{$\begin{array}{c}\text { Age } \\
\text { (yrs) }\end{array}$} & \multirow{4}{*}{$\begin{array}{c}\text { Duration of } \\
\text { Rheumatoid } \\
\text { Arthritis } \\
\text { (yrs) }\end{array}$} & \multicolumn{6}{|c|}{ Steroid Therapy } \\
\hline & & & & \multicolumn{4}{|c|}{ Previous } & \multirow{2}{*}{\multicolumn{2}{|c|}{$\begin{array}{c}\text { Present } \\
\text { Prednisone }\end{array}$}} \\
\hline & & & & \multicolumn{2}{|c|}{ Cortisone } & \multicolumn{2}{|c|}{ Hydrocortisone } & & \\
\hline & & & & $\underset{\text { Duration }}{\text { Durs) }}$ & $\begin{array}{c}\text { Dose } \\
\text { (mg./day) }\end{array}$ & $\begin{array}{c}\text { Duration } \\
\text { (yrs) }\end{array}$ & $\begin{array}{c}\text { Dose } \\
\text { (mg./day) }\end{array}$ & $\begin{array}{c}\text { Duration } \\
(\mathrm{yrs})\end{array}$ & $\begin{array}{c}\text { Dose } \\
\text { (mg./day) }\end{array}$ \\
\hline 1 & $\mathbf{M}$ & 48 & 7 & 4 & $50-100$ & 2 & 30 & 1 & 15 \\
\hline 2 & $\mathrm{~F}$ & 71 & 30 & Few mths & $50-100$ & 2 & $40-75$ & $1 \frac{1}{2}$ & $10-20$ \\
\hline 3 & $\mathbf{M}$ & 63 & 10 & 3 & $50-100$ & 1 & 75 & $1 \frac{1}{3}$ & 15 \\
\hline 4 & $\mathbf{F}$ & 61 & 6 & 5 & $25-50$ & & & $1 \frac{1}{2}$ & $10-15$ \\
\hline 5 & $\mathrm{~F}$ & 63 & 4 & $\frac{1}{2}$ & $37 \cdot 5-100$ & & & 1 & $15-25$ \\
\hline 6 & $\mathrm{~F}$ & 56 & 4 & 11 & $37 \cdot 5-100$ & & & i & $\begin{array}{l}15^{*} \\
10\end{array}$ \\
\hline 7 & $\mathbf{F}$ & 67 & 35 & & & & & $1 \frac{1}{3}$ & $10-20$ \\
\hline 8 & $F$ & 56 & 4 & 3 & $50-100$ & & & $1 \frac{1}{4}$ & $12 \frac{1}{2}$ \\
\hline 9 & $\mathbf{M}$ & 55 & 26 & 4 & $75-100$ & & & 5 & $10-15$ \\
\hline 10 & $F$ & 66 & 6 & 4 & $67 \cdot 5$ & & & $1 \frac{1}{2}$ & 20 \\
\hline 11 & $\mathrm{~F}$ & 37 & 4 & & & 1 & 10 & 1 & $10-20$ \\
\hline
\end{tabular}

* Prednisolone therapy for 9 months preceding prednisone therapy. 
TABLE II

ROUTINE LABORATORY DATA

\begin{tabular}{|c|c|c|c|c|c|c|c|c|c|c|}
\hline $\begin{array}{l}\text { Patient } \\
\text { No. }\end{array}$ & $\begin{array}{c}\text { Sensitized } \\
\text { Sheep Cell } \\
\text { Aggluti- } \\
\text { nation } \\
\text { Reaction }\end{array}$ & $\begin{array}{c}\text { Erythro- } \\
\text { cyte } \\
\text { Sedi- } \\
\text { mentation } \\
\text { Rate }\end{array}$ & V.D.R.L. & L E. Cells & $\begin{array}{l}\text { Uric } \\
\text { Acid }\end{array}$ & $\begin{array}{c}\text { Haemato- } \\
\text { crit } \\
\text { (per cent.) }\end{array}$ & $\begin{array}{c}\text { Haemo- } \\
\text { globin } \\
\text { (g. } \\
\text { per cent.) }\end{array}$ & $\begin{array}{c}\text { Red } \\
\text { Blood } \\
\text { Cells } \\
\text { (m./c.mm.) }\end{array}$ & $\begin{array}{l}\text { White } \\
\text { Blood } \\
\text { Cells }\end{array}$ & $\begin{array}{l}\text { Differential } \\
\text { (per cent.) }\end{array}$ \\
\hline 1 & Positive & 42 & & Negative & & 46 & $13 \cdot 4$ & $4 \cdot 82$ & 8,900 & $\begin{array}{l}77 \text { polymorphs } \\
21 \text { lymphocytes } \\
2 \text { eosinophils }\end{array}$ \\
\hline 2 & Positive & 33 & Negative & Negative & $\begin{array}{r}10 \cdot 5 \\
9 \cdot 0 \\
8 \cdot 0 \\
7 \cdot 1\end{array}$ & 42 & $13 \cdot 1$ & & 11,600 & $\begin{array}{l}64 \text { polymorphs } \\
32 \text { lymphocytes } \\
3 \text { monocytes } \\
1 \text { eosinophil }\end{array}$ \\
\hline 3 & Positive & 29 & Negative & & $5 \cdot 7$ & 48 & $14 \cdot 7$ & $4 \cdot 84$ & 18,100 & $\begin{array}{l}73 \text { polymorphs } \\
27 \text { lymphocytes }\end{array}$ \\
\hline 4 & Not done & 12 & Negative & Negative & & 48 & $16 \cdot 8$ & & 10,350 & $\begin{array}{l}63 \text { polymorphs } \\
31 \text { lymphocytes } \\
6 \text { monocytes }\end{array}$ \\
\hline 5 & Positive & 43 & $\begin{array}{l}\text { Weak } \\
\text { positive }\end{array}$ & Negative & $\begin{array}{l}3 \cdot 8 \\
5 \cdot 0\end{array}$ & 43 & $14 \cdot 3$ & $4 \cdot 80$ & 5,700 & $\begin{array}{l}52 \text { polymorphs } \\
45 \text { lymphocytes } \\
2 \text { monocytes } \\
1 \text { eosinophil }\end{array}$ \\
\hline 6 & Positive & 44 & Negative & Negative & $\begin{array}{l}2 \cdot 6 \\
5 \cdot 2\end{array}$ & 45 & $13 \cdot 9$ & $4 \cdot 92$ & 9.000 & $\begin{array}{l}71 \text { polymorphs } \\
26 \text { lymphocytes } \\
2 \text { basophils } \\
1 \text { eosinophil }\end{array}$ \\
\hline 7 & Positive & & Positive & Positive & $4 \cdot 0$ & 43 & $12 \cdot 9$ & $4 \cdot 52$ & 3,300 & $\begin{array}{l}5 \text { polymorphs } \\
95 \text { lymphocytes }\end{array}$ \\
\hline 8 & Positive & 43 & Negative & Negative & $\begin{array}{l}3 \cdot 4 \\
6 \cdot 4\end{array}$ & 47 & $15 \cdot 4$ & $5 \cdot 06$ & 15,800 & $\begin{array}{l}77 \text { polymorphs } \\
23 \text { lymphocytes }\end{array}$ \\
\hline 9 & Not done & 5 & & Negative & $6 \cdot 4$ & 56 & $17 \cdot 5$ & $5 \cdot 4$ & 12,400 & $\begin{array}{l}68 \text { polymorphs } \\
31 \text { lymphocytes } \\
1 \text { eosinophil }\end{array}$ \\
\hline 10 & Not done & & Negative & Negative & & 40 & $13 \cdot 0$ & $4 \cdot 0$ & 5,000 & \\
\hline 11 & Positive & 44 & Negative & Negative & $\begin{array}{l}3 \cdot 8 \\
5 \cdot 5\end{array}$ & 42 & $12 \cdot 6$ & $4 \cdot 52$ & 13,500 & $\begin{array}{l}61 \text { polymorphs } \\
38 \text { lymphocytes } \\
1 \text { basophil }\end{array}$ \\
\hline
\end{tabular}

TABLE III

COAGULATION TESTS

\begin{tabular}{|c|c|c|c|c|c|c|c|c|}
\hline \multirow{2}{*}{$\begin{array}{l}\text { Patient } \\
\text { No. }\end{array}$} & \multirow{2}{*}{$\begin{array}{c}\text { Platelets } \\
(1,000 / \text { c.mm. })\end{array}$} & \multicolumn{2}{|c|}{$\underset{\text { Time }}{\text { Bleeding }}$} & \multicolumn{2}{|c|}{$\underset{\text { Time }}{\text { Coagulation }}$} & \multirow{2}{*}{$\begin{array}{l}\text { Fragili- } \\
\text { meter }\end{array}$} & \multicolumn{2}{|c|}{ Prothrombin } \\
\hline & & Min. & Sec. & Min. & Sec. & & $\begin{array}{l}\text { Time } \\
\text { (sec.) }\end{array}$ & $\begin{array}{l}\text { Per cent. } \\
\text { of Normal }\end{array}$ \\
\hline 1 & 258,000 & & & & & & $15 \cdot 2$ & Above 110 \\
\hline 2 & 282,000 & 1 & 45 & 4 & & Normal & $15 \cdot 8$ & 100 \\
\hline 3 & 194,000 & 2 & 25 & 3 & & Normal & $16 \cdot 0$ & 100 \\
\hline 4 & 218,000 & 1 & 50 & 3 & 40 & & 15 & 100 \\
\hline 5 & 127,000 & 1 & 50 & 5 & & Normal & $16 \cdot 6$ & 100 \\
\hline 6 & 224,000 & 1 & & 5 & 30 & Normal & 16 & 100 \\
\hline 7 & 230,000 & & & & & Normal & $14 \cdot 1$ & 120 \\
\hline 8 & 287,000 & & 45 & 2 & & & $14 \cdot 9$ & Above 110 \\
\hline 9 & 178,000 & & & & & Normal & $18 \cdot 1$ & 65 \\
\hline 10 & 150,000 & & & & & & $15 \cdot 3$ & 110 \\
\hline 11 & 269,000 & & 25 & 3 & & Normal & $16 \cdot 5$ & 100 \\
\hline
\end{tabular}


and the pressure held half-way between systolic and diastolic for 5 minutes. There was no evidence of decreased capillary resistance by this technique.

Other special coagulation investigations included the recalcification time, prothrombin consumption, thrombin time, coagulogram, and fibrinolysis. ${ }^{*}$ No significant abnormalities were found in any of these special studies.

Serum proteins, determined by the method of Jencks, Jetton, and Durrum (1955), revealed a reversal of the albumin/globulin ratio in three of the nine cases studied. The electrophoretic pattern showed a decreased albumin content with an increased alpha 1 and alpha 2 globulin, a moderately elevated beta globulin, and an increased gamma globulin (Table IV). These findings are similar to those reported by Houli and Hasson (1956) in a series of patients with rheumatoid arthritis.

The blood ascorbic acid levels were measured in eight of these eleven subjects and the content was decreased in each instance. It is well known that the vitamin $C$ levels may be low in patients with rheumatoid arthritis without steroid therapy, and this finding was therefore not unexpected.

Skin biopsies of these lesions were taken from four patients. No significant changes were observed in the routine haematoxylin and eosin stained sections which would explain the extravasation of blood.

* These determinations were made by Dr. Kurt von Kaulla of the Coagulation Laboratory of the University of Colorado Medical Centre.

\section{Discussion}

The occurrence of spontaneous skin haemorrhages is a classical finding in Cushing's syndrome and has been repeatedly observed in the hypercortisonism produced in patients receiving exogenous adrenocorticosteroids and adrenocorticotropin. The observed increased frequency of these purpuric spots after prednisone therapy which forms the basis of this report and the observed increased incidence noted by Black and others (1957), Denko and Schroeder (1957), and Boland (1957) would appear to be an exaggeration of this well-recognized tendency to easy bruising. When our attention was drawn to this undesirable side-effect, a search was made of the literature to determine what factors might have been previously considered to bear a direct relationship to the observed cutaneous haemorrhages. Few reports have been found which bear directly on this point and only two (Black and others, 1957; Denko and Schroeder, 1957) dealt directly with bleeding and coagulation studies. Among the battery of blood studies done in the nine patients investigated by Denko and Schroeder (1957), the only test that was consistently abnormal was a positive Rumpel-Leede phenomenon. The decreased capillary resistance reflected by this tesh was suggested as a contributory factor to the skip haemorrhages observed in patients with hyper cortisonism. Increased capillary fragility was demon strated by a positive Rumpel-Leede phenomenon in six out of seven patients reported by Black and others (1957). In our efforts to measure this

TABLE IV

SERUM PROTEINS

\begin{tabular}{|c|c|c|c|c|c|c|c|c|c|}
\hline \multirow[b]{2}{*}{$\begin{array}{c}\text { Patient } \\
\text { No. }\end{array}$} & \multirow[b]{2}{*}{$\begin{array}{l}\text { Fibrinogen } \\
\text { (mg.) }\end{array}$} & \multirow[b]{2}{*}{$\begin{array}{c}\text { Total } \\
\text { (g.) }\end{array}$} & \multirow[b]{2}{*}{$\underset{\text { (g.) }}{\text { Albumin }}$} & \multirow[b]{2}{*}{$\begin{array}{l}\text { Globulin } \\
\text { (g.) }\end{array}$} & \multirow[b]{2}{*}{$\begin{array}{l}\text { Albumin } \\
\text { (per cent.) }\end{array}$} & \multicolumn{4}{|c|}{ Electrophoresis } \\
\hline & & & & & & $\begin{array}{c}\text { Alpha } 1 \\
\text { (per cent.) }\end{array}$ & $\underset{\text { (per cent.) }}{\text { Alpha } 2}$ & $\begin{array}{c}\text { Beta } \\
\text { (per cent.) }\end{array}$ & $\begin{array}{c}\text { Gamma } \\
\text { (per cent.) }\end{array}$ \\
\hline Norma & Values(10) & & & & $70 \cdot 8$ & $2 \cdot 7$ & $5 \cdot 7$ & $8 \cdot 3$ & $12 \cdot 6$ \\
\hline 1 & $0 \cdot 334$ & & & & 57 & 5 & 11 & $7 \cdot 9$ & $19 \cdot 1$ \\
\hline 2 & $0 \cdot 342$ & $6 \cdot 75$ & $3 \cdot 75$ & $3 \cdot 0$ & $54 \cdot 4$ & $5 \cdot 2$ & $13 \cdot 1$ & $13 \cdot 2$ & $\overline{14} \cdot 1$ \\
\hline 3 & $0 \cdot 301$ & $6 \cdot 70$ & $4 \cdot 16$ & $2 \cdot 54$ & $62 \cdot 2$ & $15 \cdot 5$ & 11 & $8 \cdot 9$ & $12 \cdot 2$ \\
\hline 4 & 0.405 & $5 \cdot 7$ & $3 \cdot 4$ & $2 \cdot 3$ & & & & & \\
\hline 5 & 0.411 & $7 \cdot 24$ & $4 \cdot 02$ & $3 \cdot 22$ & $66 \cdot 7$ & $3 \cdot 2$ & $7 \cdot 9$ & $8 \cdot 8$ & $13 \cdot 4$ \\
\hline 6 & $0 \cdot 364$ & $7 \cdot 20$ & $3 \cdot 77$ & $3 \cdot 43$ & $60 \cdot 2$ & $4 \cdot 3$ & $10 \cdot 2$ & $10 \cdot 4$ & $14 \cdot 9$ \\
\hline 7 & $0 \cdot 376$ & $7 \cdot 62$ & $3 \cdot 7$ & $3 \cdot 92$ & $52 \cdot 2$ & $5 \cdot 2$ & $10 \cdot 3$ & $11 \cdot 2$ & $20 \cdot 8$ \\
\hline 8 & $0 \cdot 292$ & $7 \cdot 19$ & $3 \cdot 56$ & $3 \cdot 63$ & $54 \cdot 9$ & $8 \cdot 4$ & $10 \cdot 0$ & $9 \cdot 8$ & $16 \cdot 9$ \\
\hline 9 & $0 \cdot 284$ & & & & $62 \cdot 7$ & $4 \cdot 0$ & $9 \cdot 1$ & $9 \cdot 5$ & $14 \cdot 7$ \\
\hline 10 & 0.500 & $7 \cdot 1$ & $3 \cdot 0$ & $4 \cdot 1$ & & & & & \\
\hline 11 & $0 \cdot 308$ & $7 \cdot 17$ & $3 \cdot 99$ & $3 \cdot 18$ & $63 \cdot 5$ & $4 \cdot 0$ & $9 \cdot 8$ & $8 \cdot 5$ & $14 \cdot 2$ \\
\hline
\end{tabular}


capillary function, negative pressure was applied using a fragilimeter and also by the Rumpel-Leede method. By the former technique, nine of ten patients studied had no evidence of a decreased capillary resistance; by the latter, six patients were tested and none showed decreased capillary resistance.

It is difficult to reconcile the wide use of prednisolone for the control of ecchymosis and spontaneous skin petechiae in a variety of haemorrhagic diseases with the occurrence of haemorrhagic lesions in this and other similar reports. At present there appears to be no answer to this apparent paradox.

The ease with which these haemorrhages occur after minor trauma has been demonstrated in several of our patients by slapping the uninvolved forearm of a patient with this tendency with a wooden spatula and observing the rapid development of subcutaneous bleeding. Among the factors which might contribute to this phenomenon is the lack of the normal haemostatic mechanism in the pericapillary tissues. This is supported by the failure to demonstrate any defects in the intravascular coagulation mechanisms and, in our hands, no abnormality in the capillary wall itself. Blunt trauma may cause a rent in the capillary wall which is not immediately plugged, and because of intracapillary pressure more and more cells are extruded through this opening to produce a macroscopic lesion.

In the course of these investigations our attention has again been called to the similarity of the lesions described in this paper to those seen frequently in older people with atrophic senile skin. In these old people the distribution of lesions is the same as that seen in patients with rheumatoid arthritis treated with prednisone, the chief sites being the exposed parts of the body, especially the hands and other areas subject to frequent minor trauma. There are several features common to these two conditions. Both the senile skin and that of the patient with rheumatoid arthritis is atrophic and the lack of the pericapillary fat tissue may deprive both subjects of the protective buffering or cushioning quality of subcutaneous fatty tissue. Another common finding might be a generalized "protein depletion" with alterations in the subcutaneous structures which in some as yet unknown way contributes to the inability to control the capillary injury.

\section{Summary}

Purpuric lesions were observed in 44 of 109 patients ( 40 per cent.) with rheumatoid arthritis who had received long-term steroid therapy. The incidence of these skin haemorrhages appeared to be greater since the introduction of the so-called delta-1 or meta drugs. The most common sites of these lesions were the forearms, wrists, and dorsa of the hands and fingers, and they occurred without apparent cause or after minor trauma. Extensive laboratory studies, including coagulation factors, capillary resistance and fragility, and serum electrophoretic patterns, failed to demonstrate the mechanism of production of the observed haemorrhagic lesions.

The ease with which subcutaneous bleeding was produced in a susceptible individual by blunt trauma suggests that the lack of the normal haemostatic mechanism in the pericapillary tissues may be a major contributory factor in this phenomenon. The final explanation for this bleeding tendency must await further study.

The authors acknowledge the valuable assistance of Dr. Kurt von Kaulla in this study.

\section{REFERENCES}

Black, R. L., Yielding, K. L., and Bunim, J. J. (1957). J. chron. Dis., $\mathbf{5}, 751$.

Boland, E. W. (1956). J. Amer. med. Ass., 160, 613.

(1957). Med. clin. N. Amer., 41, 553.

Brown, E. A. (1956). Clin. Med., 3, 119.

Denko, C. W., and Schroeder, L. R. (1957). J. Amer. med. Ass., 164, 41 .

Houli, J., and Hasson, A. (1956). Rheumatism, 12, 52.

Jencks, W. P. Jetton, M. R., and Durrum, E. L. (1955). Biochem. J., 60,205 .

Kinsell, L., Michaels, G., Coehlo, M., Foreman, N., and Friskey, R. "A.M.A. Scientific Exhibits, 1955", pp. 189-98 (American Medical Association Council on Scientific Assembly). Grune Medical Association Council
and Stratton, New York.

Neustadt, D. H., McClendon, R., Olash, F. H., and Best, M. (1956). J. Kentucky med. Ass., 54, 131.

Solem, J. H., and Rømcke, O. (1956). T. norske Lageforen., 76, 321 Ziff, M., Brown, P., and McEwen, C. (1954). Bull. rheum. Dis., $5,75$.

Hémorragies sous-cutanées chez des malades rhumatisants traités par la prednisone

\section{RÉSUMÉ}

Des lésions de purpura furent observées chez 44 sur 109 malades $(40 \%)$ atteints d'arthrite rhumatismale et ayant subi une thérapie stéroïde pendant des périodes prolongées. La fréquence de ces hémorragies souscutanées semblait avoir augmenté depuis l'introduction des produits nommés delta-1 ou méta. Le plus souvent on trouvait ces lésions aux avant-bras, les poignets, le dos des mains et des doigts; elles survenaient sans cause apparente ou bien après un traumatisme peu important. Des examens de laboratoire minutieux, comprenants les facteurs d'agglutination, la résistance et la fragilité capillaire, et d'étude électrophorétique du sérum, ne révélèrent pas le mécanisme par lequel ces lésions hémorragiques auraient pu se produire.

La facilité avec laquelle une hémorragie sous-cutanée chez un sujet susceptible se produisait après un cognement, suggère que l'absence du mécanisme hémostatique normal dans les tissus péricapillaires serait un facteur contributif majeur. L'explication finale de cette tendance hémorragique demande des études ultérieures. 
Hemorragias subcutáneas en enfermos reumáticos tratados con la prednisona

\section{Sumario}

Lesiones de púrpura fueron observadas en 44 de los 109 enfermos $(40 \%)$ con artritis reumatoide que habian recibido una terapia esteroide durante un período prolongado. La frecuencia des estas hemorragias subcutáneas pareció haber aumentado con la introducción de los productos llamados delta-1 o meta. Se encontraban estas lesiones generalmente en los antebrazos, las muñecas, el dorso de las manos y de los dedos; aparecian sin causa aparente o después de un leve traumatismo. Investigaciones detalladas de laboratorio, comprendiendo los factores de aglutinación, la resistencia y la fragilidad capilar y el cuadro electroforético del suero, no revelaron el mecanismo por el cual estas lesiones hemorrágicas se producían.

La facilidad con que una hemorragia subcutánea se produce en un sujeto susceptible, sugiere que la ausencia del mecanismo hemostático normal en los tejidos pericapilares sería un factor contribuyente mayor. La explicación final de esta tendencia hemorrágica necesita estudios ulteriores. 